\title{
Various aesthetic results in the primary surgical treatment of bitten face wounds in children
}

\section{${ }^{1}$ JSC "Medical University of Astana; \\ ${ }^{2}$ City Children's Hospital enterprise on economic management №2 of Astana city}

Batyrly Tuleubay ${ }^{1}$, Zhakanov Tuleu $^{2}$, Aulybay Dauken ${ }^{2}$

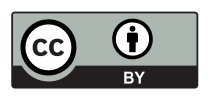

J CLIN MED KAZ 2017; 3(45 SUPPL 3):77-83 Автор для корреспонденции: Ибраимов Б. А. Корпоративный фонд «UniversityMedicalCenter» Национальный научный центр материнства и детства, патолого анатомическое отделение, ул.Туран 32 , Астана, Казахстан.

Телефон: 8-701-354-41-50, E-mail:Ibraimov@inbox.ru

\author{
ABSTRACT \\ Bitten wounds inflicted by animals on the face of children are special. Deforming scars \\ can then only be corrected by a series of operations. However, in the early primary surgical \\ treatment of bitten wounds of children with the use of a special complex multidisciplinary \\ and hardware approach in the conditions of the children's maxillofacial department, it is \\ possible to achieve significantly optimal results. \\ Key words: Bite wounds, face, nose, eyes, tear ducts, trauma, primary surgical treatment \\ (PST), complications of facial wounds.

\section{БАЛАЛАРДЫН БЕТІНЕ ЖАНУАРЛАРДЫН ТІСТЕП САЛҒАН ЖАРАҚАТЫНА АЛҒАШКЫ ХИРУРГИЯЛЫК ӨНДЕУДЕГІ ӘРТУРЛІ ЭСТЕТИКАЛЫК НӘТИЖЕЛЕРІ \\ Батырұлы Т.О.', Жақанов Т.В. ${ }^{2}$, Аулыбай Д.С. ${ }^{2}$ \\ ${ }^{1}$ «Астана медицина университеті» АҚ \\ 2 Шаруашылық басқарудағы мекеме «Астана қаласы №2 балалар ауруханасы»}

\section{АБСТРАКТ}

Балалардың бетіне жануарлардың тістеп салған жарақаты ерекше. Деформация болып біткен кейінгі тыртықтарды тек бірнеше операциямен ғана түзетіле алады, алайда, бет-жақсүйек хирургиясы бөлімінде арнайы комплексті көпсалалы және аппараттық тәсілмен балалардың жараланған жарақаттарына алғашқы хирургиялық өңдеуді ерте өткізсе оңтайлы нәтижелерге қол жеткізуге болады.

Түйінді сөздер: тістеп салған жарақат, бет, мұрын, көздер, көзжас түтүктері, жарақаттар, алғашқы хирургиялық өңдеу (AXӨ), бет жарақаттарының асқынуы.

\author{
РАЗЛИЧНЫЕ ЭСТЕТИЧЕСКИЕ РЕЗУЛЬТАТЫ ПРИ ПЕРВИЧНО- \\ ХИРУРГИЧЕСКОЙ ОБРАБОТКЕ УКУШЕННЫХ РАН ЛИЦА У ДЕТЕЙ \\ Батырұлы Т.О.' ${ }^{1}$ Жақанов Т.В. ${ }^{2}$, Аулыбай Д.С. ${ }^{2}$ \\ ${ }^{1}$ АО «Медицинский университет Астана \\ ${ }^{2}$ ГДБ на ПХВ №2 г. Астана
}

\section{АБСТРАКТ}

Укушенные раны нанесенные животными в область лица детей, являются особенными. Деформирующие рубцы впоследствии удается исправить лишь серией операций.Однако при ранней первично-хирургической обработке укушенных ран лица детей с применением специального комплексного мультидисциплинарного и аппаратного подхода в условиях детского челюстно-лицевого отделения, можно добиться значительно оптимальных результатов.

Ключевые слова: Укушенные раны, лицо, нос, глаза, слезные протоки, травмы, первичная хирургическая обработка (ПХО), осложнения ран лица.

\section{Введение \\ Укушенные раны лица у детей могут сопровождаться анатомическими и функциональными расстройствами. Челюстно-лицевая область у ребенка является особенной, так как постоянно находится в развитии. В отличие от взрослых, лицо ребенка меняется с возрастом, полученные удовлетворительные ближайшие результаты хирургического лечения могут не устраивать в будущем, что потребует выполнения повторных операций для улучшения эстетики лица [1,2]. Рассматриваемая анатомическая область}

имеет обильное кровоснабжение, что подразумевает хорошие репаративные возможности тканей и быстрое заживление повреждений[3]. Однако наблюдались случаи формирования некрозов, развитие гнойных осложнений, а также образование грубых рубцовых деформаций лица у детей. Несмотря на хорошее кровоснабжение и иннервацию, возникшие осложнения привели к необходимости повторных операций. Таким образом, данная проблема имеет не только медицинский, но и яркий социальный характер и требует пристального внимания, тем более этот травматизм растет[4]. 


\section{Описание клинического случая 1.}

Ниже приводим случай из нашей практики: Ребенок А. 3,5 лет доставлен скорой помощью в ГДБ №2 г. Астаны в течение часа, после укуса домашней собаки, после осмотра дежурных врачей - офтальмолога и челюстно-лицевого хирурга, госпитализирован в отделение офтальмологии. При осмотре состояние средней степени тяжести, за счет полученной травмы, температура нормальная. Самочувствие страдает. Рвоты тошноты нет.

Местно: Височной области справа имеется рваноукушенная рана мягких тканей размером $3.0 * 2,5 \mathrm{~cm}$, начинающаяся от наружного угла правого глаза. OD: веки отечны. На нижнем веке рваная рана с разрывом по реберному краю век, с повреждением нижнего слезного канала. Конъюнктива отечная, рыхлая, из раны - геморрагическое отделяемое. Роговица прозрачная. Передняя камера средней глубины, влага прозрачная. Радужка структурная. Зрачок округлой формы, реакция на свет живая. Хрусталик прозрачный, острота зрения - предметное зрение имеется. OS: здоров. Глазное дно ОИ: ДЗН бледно-розовое, границы четкие. А: В в пределах возрастных норм; сетчатка розовая; макулярный рефлекс розовый. Лабораторные данные в пределах нормы, гемоглобин понижен ( $\mathrm{Hb}-100 г / л$.$) . На$ рентгенограмме черепа в $2 \mathrm{x}$ проекциях данных за инородное тело в области раны и перелома костей орбиты не выявлены.

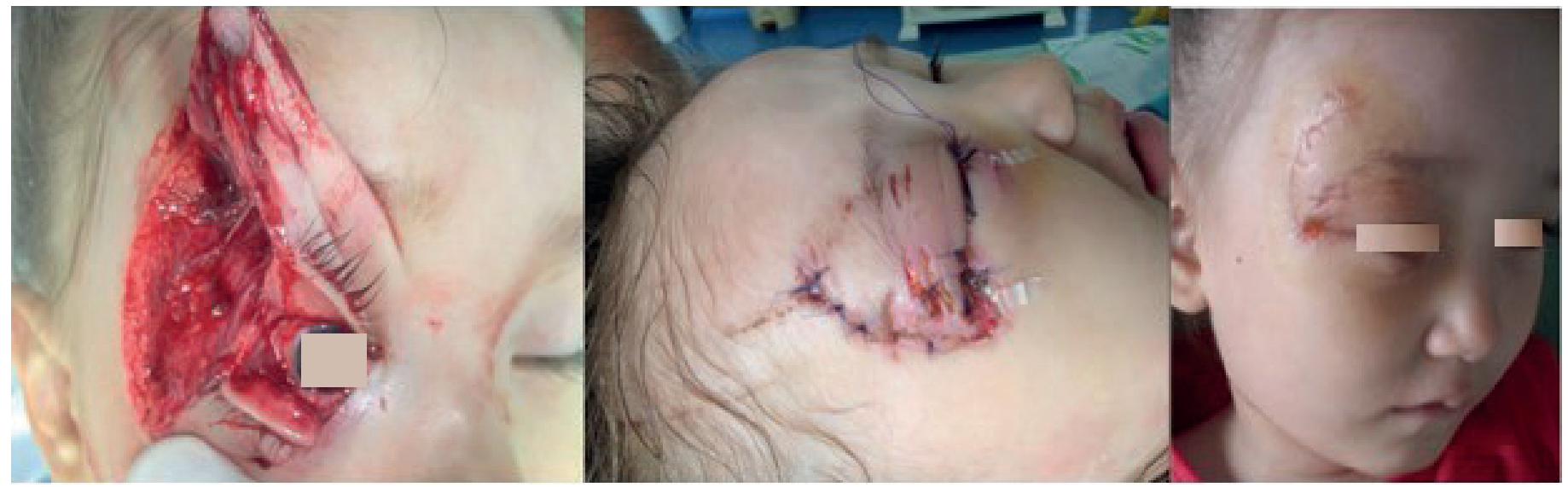

Рисунок 1 - Ребенок А. 3,5лет. Укушенная открытая рана века и окологлазничной области справа (динамика лечения).

Выставлен диагноз основной: Открытая рана века и окологлазничной области, III категория. Сопутствующие диагнозы: Открытая рана неуточненной области тела. Открытая рана других областей головы. Другие уточненные анемии.

Проведено лечение: 1. Под внутривенным наркозом проведено экстренно ПХО раны окологлазничной области справа, с ревизией раны височной области и нижнего века с восстановлением разрыва нижнего слезного канала. Хирургическую обработку проводили с учетом требований пластической хирургии, иссечение тканей было щадящее - удалены только явно нежизнеспособные ткани. После проведения антисептической обработки раны правильно сопоставили ткани. Их ушивали послойно, восстанавливая непрерывность мышц подкожно-жировой клетчатки, кожные покровы сшивали стык в стык, не допуская чрезмерного натяжения. Восстановили разрыв нижнего слезного канала сопоставление, и сшивание краев проводили более тщательно. Хирургическая обработка ран выполнялась мультидисциплинарной бригадой (офтальмохирурги, челюстно-лицевые хирурги), с применением микроскопа. Оставлен резиновый выпускник. Асептическая повязка на рану.

2.Антибактериальная терапия-Цеф-3 по 700мг*2 раза в день внутривенно № 14; Метрид из расчета 7,5 мг/кг по 30,0мл.*3раза в сутки внутривенно капельно №6.

3.Десенсебилизирующая терапия: Аллергозан 25мг по 1/2таб.*2 раза в день внутрь.

4.Профилактика дисбактериоза-пробиотик Смекта 1пачка *2 раза в день.

5. Профилактическая прививка против бешенства по назначению травматолога: Эквираб 3 раза с интервалом через 2 дня.
6.Местно промывание раны раствором Метрида-10мл * 2 раза в день, перевязки с гипертоническим раствором и на стадиях заживления с мазью Левомеколь.

Ветеринарное обследование домашней собаки от 12.07.2016г.: Признаки бешенства не обнаружены.

На 16 день больная выписалась с выздоровлением. Общее состояние при выписке удовлетворительное. Сон и аппетит не нарушены. Температура тела нормальная. Ребенок активный. Рвоты не было. Кожные покровы обычные, чистые. Видимые слизистые оболочки влажные, бледно-розового цвета. Язык влажный, без налета. Диурез и стул не нарушены.

Локальные данные: OS-спокоен. OD- спокоен. OD глазная щель открывается в полном объеме, конъюнктива в норме, без патологии, пальпация безболезненная. Послеоперационная рана чистая, заживление первичным натяжением, оптические среды прозрачные. Острота зрения: OU- предметное зрение. Глазное дно: ОU:ДЗН бледнорозовый, границы четкие, калибр сосудов не изменен, сетчатка розова, макулярный рефлекс розовый.

Рекомендовано: 1. Избегать травмы. 2. Консультация педиатра (по поводу анемии средней степени). 3. Смазывание рубцов мазью «Контрактубекс» в течение нескольких месяцев.

4. Электрофорез лидазы на область рубцов № 10 через день.

5. При наличии болезненных гипертрофических рубцов - фонофорез гидрокортизона № 8-10.

6. Парафинотерапия или аппликации озокерита через день № 10.

7. Повторить анализы крови через месяц.

8. Повторный прием ЧЛХ через 6 месяцев. 


\section{Описание клинического случая 2.}

Ниже приводим случай из нашей практики по выписке:
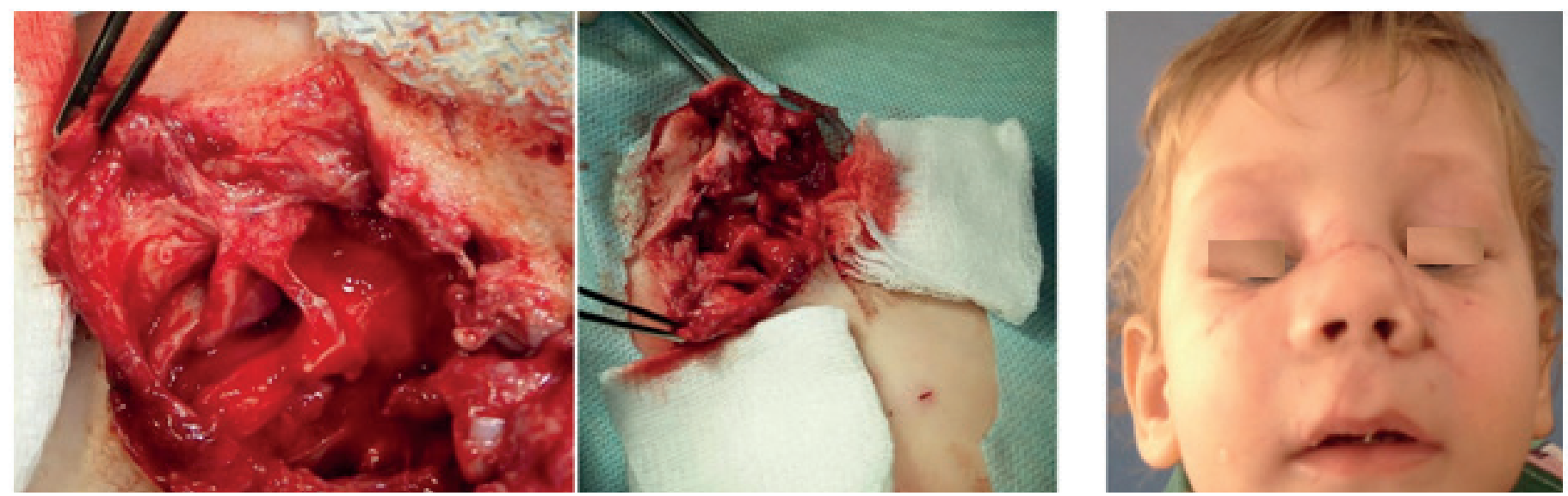

Рисунок 2 - Ребенок В.- 2г. Укушенная открытая рана носа (динамика лечения).

Ребенок: В. 14.09.14 г/p. по экстренным показаниям госпитализирован в отделение детской челюстно-лицевой хирургии ГКП на ПХВ «ГДБ №2» 19.09.2016 г. с жалобами на укушенную рану носа.

Anamnesis morbi: Со слов мамы ребенок получил травму во дворе домашней собакой. Ребенок сознание не терял, тошноты рвоты не было. Обратились 19.09.2016 в приемный покой ГДБ№2, осмотрен челюстно-лицевым хирургом, совместно с ЛОР врачом, госпитализирован в экстренном порядке в отделение ЧЛХ.

Anamnesis vitae: 3-й ребенок от 3-й беременности. Вес при рождении 3300, рост 51 см. Развит соответственно возрасту. Гепатит, туберкулез, отрицает. Непереносимость к лекарственным препаратам отрицают. Детские инфекции отрицают. На «Д» учете нигде не состоит. Аллергоанамнез не отягощен. Наследственность не отягощена.

Status localis: Асимметрия лица за счет укушенной раны носа мягких тканей верхней губы и подглазничной области справа. Кожа над раной гиперемирована, отечна.

В полости рта: слизистая оболочка разорвана в области верхней губы по переходной складке от 5.5. зуба до 6.5 и сообщается с носовым ходом, гиперемирована, истончена, отечна, рана кровоточит.

Консультация травматолога: Множественные укушенные раны носа, верхней губы, подбородочной области справа и лобной области слева, 3 категории.

Консультация офтальмолога: Укушенная рваная рана нижней окологлазничной области правого глаза.

Консультация ЛОР: Укушенная рана наружного носа, нижнего века справа, верхней губы, лобной области слева

Диагноз: Укушенная рана носа, верхней губы, подбородочной области справа и лобной области слева. III-я категория.

План обследования: 1.Общий анализ крови и мочи. 2.Бак посев из раны.3.Кал, соскоб на я/г. 4.Группа крови, резус-фактор.

В день поступления под общим наркозом произведено операция: Хирургическая обработка раны, дренирование. Протокол операции: После медицинской обработки операционного поля под общим наркозом произведена ПХО раны, пластика носа. Рана промыта 3\% раствором перекиси водорода, раствором повидон-йода. Оставлен резиновый выпускник. Асептическая повязка на рану. Объем кровопотери: 3.0 мл.

План послеоперационного лечения: 1.Цефтазидим по 750 внутривенно 2 раза в день.

2. Анальгин $50 \%$ по 0.2 мл внутримышечно 2 раза в день. 3.Димедрол 1\% по 0.2 мл внутримышечно 2 раза в день. 4.Хилак форте по 10 кап. 3 раза в день.5. Ежедневно перевязки - под повязкой с мазью на полиэ-тиленоксидной основе («Левомеколь»).

- Профилактическая прививка против бешенства по назначению травматолога - Эквираб 3 раза с интервалом через 2 дня 0, 3, 7-й дни пока идет наблюдение за животными.

В течение 10 дней ребенку проводились соответствующее плану лечение, послеоперационная рана зажила первичным натяжением. Лабораторные данные в динамике без существенных изменений.

По просьбе родителей ребенок выписан из стационара на 11 день пребывания.

Местно: Асимметрии лица не наблюдается. Кожные покровы чистые обычной окраски. Регионарные лимфатические узлы не увеличены. Послеоперационная рана в области носогубной складки справа заживает первичным натяжением. Признаков воспаления нет. На день выписки общее состояние ребенка удовлетворительное. Жалоб нет.

Рекомендовано амбулаторное лечение, по месту жительства:

1) Точечный массаж, начиная с 12-14 дня после операции.

2) Механотерапия или миогимнастика.

3) Смазывание рубцов мазью «Контрактубекс» в течение нескольких месяцев.

4) Электрофорез лидазы на область рубцов № 10 через день.

5) При наличии болезненных гипертрофических рубцов - фонофорез гидрокортизона № 8-10.

6) Парафинотерапия или аппликации озокерита через день № 10 . 


\section{Описание клинического случая 3, с разбором судебно-медицинской экспертизы.}

Ниже приводим копию экспертного заключения и ответов независимого аккредитованного эксперта, на вопросы

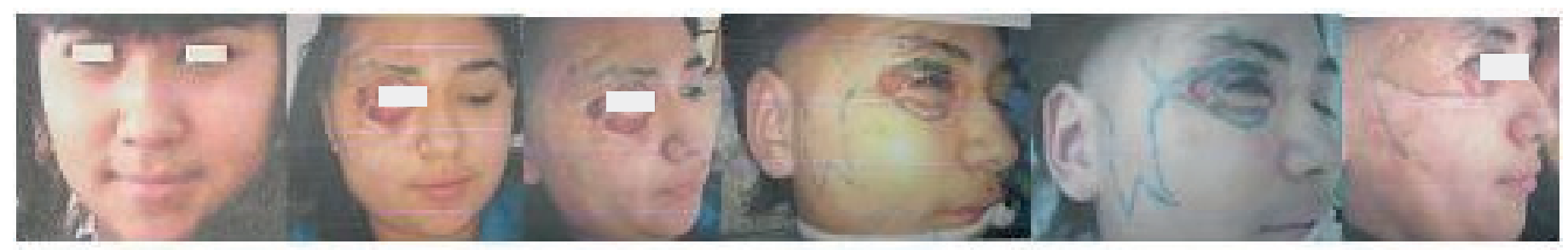

Рисунок 3 - Больная Ш. Последствия неудачной ПХО открытой раны окологлазничной и скуловой области, приведщая к некрозу мягких тканей, которых восстанавливают длительное время (1 сегмент до травмы; 2-5 этапы лечения).

поставленные старшим дознавателем ОР УД ДВД Д. на их разрешение:

Вопрос 1. Имеется ли факт ненадлежащего оказания первой медицинской помощи Ш. при первоначальном ее поступлении в городскую больницу?

Ответ: Да имеется. 1.В отделении нейрохирургии городской больницы динамика местного статуса (состояние раны лица) с момента поступлении в стационар-18.02.12г. не описывается, соответственно нет записи о проведенном местном лечении раны лица. Первая краткая запись в дневнике появляется за 21.02.12г.,- перевязана рана, промыта, дренирована.

2. Антибактериальное лечение (цеф-3; метрид) назначается только на третий день (20.02.) это при диагнозе инфицированная рана, является нарушением протокола диагностики и лечения.

3.Не проведен бактериальный посев из отделяемого раны для определения вида флоры и чувствительности к антибиотикам и соответственно своевременно не проведена адекватная антибактериальная терапия.

4. Консультация челюстно-лицевого хирурга проводится только 21.02.12г на четвертые сутки нахождения больной в стационаре, что также является нарушением протокола диагностики и лечения. Все раны лица должны лечить челюстно-лицевой хирург, даже если больной нетранспортабелен, должен быть вызов специалиста из других клиник. В частности экстренную больную с раной лица и переломом скуловой кости с первого дня должен лечить челюстно-лицевой хирург, независимо от места госпитализации!!!

Вопрос 2. Что конкретно явилось причиной возникновения рожистого воспаления флегмонознонекротической формы, повлекшее расплавление мягких тканей век правого глаза больной Ш. (повышенная загрязненность и потливость кожи при недостатках личной гигиены либо плохая организация оказания медицинской помощи)?

Ответ. Течение и клинику рожистого воспаления более квалифицированно описывать может инфекционист.

Вопрос 3. Из-за действий (бездействий) каких конкретных врачей, осуществляющих медицинские манипуляции и оказывавших первую медицинскую помощь Ш., наступили последствия в виде формирования рубцов на лице Ш.?

Ответ. При любой травме на лице могут возникнуть рубцовое заживление. Это естественный процесс регенерации тканей при глубоком (с захватом росткового слоя кожи) повреждении. При осложненном течении раны, в частности гнойно-некротическом поражении, как у больной Ш. рубцы могут образоваться с дефектом тканей из-за большого участка поражения, которому впоследствии требуется дополнительная пластическая операция. При правильномпроведениипервичнойхирургическойобработке ран лица и уходе за раной - ежедневной антисептической обработке, ревизии раны и адекватного дренирования возможности гнойно-некротического осложнения свелись бы к нулю. При этом рубцевания раны прошло бы без дефекта. По записи медицинской документации нет сведений о лечении местной раны надбровной области, в отделении нейрохирургии городской больницы. 18.02-21.02 12 г, что предполагает о бездействии в отношении местной раны врачей этого отделения, в частности лечащий врача В., который подписывал медицинскую карту № 1885/1146.

Вопрос 4. Явилось ли ненадлежащее оказание врачами первой медицинской помощи причиной наступления последствий в виде формирования рубцов на лице Ш.?

Ответ. При осложненном течении раны, в частности гнойно-некротическом поражении, как у больной Ш. рубцы могут образоваться с дефектом тканей из-за большого участка поражения, которому впоследствии требуется дополнительная пластическая операция. Больной Ш. не в полном объеме оказана медицинская помощь в городской больнице, что привело к обширному гнойно-некротическому поражению мягких тканей околоорбитальной области и применению последующей пластики, при которым сформировались рубцы.

Вопрос 5. Какова вероятность образования рубцов при своевременной квалифицированной медицинской помощи Ш.?

Ответ. Вероятность рубцевания раны всегда 100\%. Но рубец рубцу рознь. При правильном проведении первичной хирургической обработки ран лица и уходе за раной - ежедневной антисептической обработке, ревизии раны и адекватного дренирования - возможности гнойнонекротического осложнения свелись бы к нулю. При этом рубцевания раны прошло бы без дефекта. И не было бы необходимости проводить большие лоскутные пластические операции. Небольшие рубцы иссекаются с проведением вторичной операции и наложением косметических швов. Больные переносят такие операции обычно безболезненно.

\section{Обсуждение.}

В литературе нет единого мнения тактике лечения укушенных ран лица. При немедленном обращении к специалистам челюстно-лицевой хирургии и после первично-пластической операции, комплексного подхода в лечении можно добиться неплохих результатов. Полагается, что обильное кровоснабжение лица и немедленное 
обращение в стационар - факторы, обеспечивающие удовлетворительные результаты действий челюстнолицевых и пластических хирургов. Низкая частота осложнений после первично-пластической операции при укушенных ранах лица позволяет считать эти раны не более опасными в плане нагноения, чем другие раны лица, например полученные при автомобильных авариях $[1,3]$.

Тем не менее, раны, нанесенные животными в область лица, являются особенными [5]. Деформирующие рубцы впоследствии удается исправить лишь серией операций. Лицо имеет участки, предрасположенные к формированию келоидных рубцов (верхняя губа, внутренний угол глаза, латеральные области щек), что не всегда позволяет добиться удовлетворительного результата лечения [6]. Повреждение окологлазничной области и орбиты по данным некоторых авторов колеблется от $1,07 \%$ до $2,7 \%$ от общего числа офтальмологических больных и приближается к 4\% от больных с травмами органа зрения.

По виду раны век делят на резаные, рваные и колотые. По характеру раны различают на несквозные, сквозные: без поражения свободного края и с поражением свободного края, в том числе с частичным или полным отрывом века. При несквозном ранении века повреждается кожа, а иногда и мышечный слой. При сквозном ранении повреждаются все слои века, в том числе и его хрящ. При разрыве века сквозная рана открыта (зияние), края ее оттягиваются волокнами разорванной круговой мышцы. Особую клиническую форму представляет отрыв века. Иногда при таких ранениях обнаруживается дефект ткани век. Разрывы слезных канальцев имеют место при ранениях и отрывах век во внутреннем углу глазной щели, как описанном нами случае больной А.

Края раны, нанесенной животным, в течение первых трех дней рекомендуют не иссекать, а саму рану - не ушивать. Исключение составляют повреждения, которые требуют специальных хирургических вмешательств по жизненным показаниям (обширные раны, в целях остановки кровотечения) [7]. К сожалению, при такой обработке раны лица отмечают осложнения в виде абсцессов и флегмон, образования слюнных свищей, формирования грубых келоидных рубцов [8]. В развитииосложненийв 75\% ведущую роль играют местные факторы: травматизация тканей, недостаточная хирургическая обработка, необоснованное применение глухого шва, неадекватное дренирование, пренебрежение правилами асептики и антисептики [9]. ПХО раны следует проводить под наркозом (кроме поверхностных ран длиной 1-3 см) . Доказано замедление сроков течения раневого процесса у лиц, оперированных под местной анестезией, что обусловлено несовершенством оперативного пособия [10]. После обработки кожи 70\% спиртом, раневой поверхности - 3\% раствором перекиси водорода и слабым раствором перманганата калия осуществляют ревизию раны. Особое внимание уделяют ранам, находящимся вблизи физиологических отверстий, проникающим в полость рта, носа, а так же расположенным в проекции околоушных слюнных желез (возможно ранение лицевого нерва и выводного протока железы). При ранениях орбитальной области чаще страдает нижнее веко и слезный проток. Восстановление выводного слезного протока с использованием микрохирургической техники, как в нашем случае с больной А., позволили сохранить функцию органа зрения ребенка и избежать повторных операций [11]. Ревизия всех раневых каналов делает возможным уточнить топографию повреждения, удалить инородные тела, опорожнить гематомы, выполнить гемостаз [7]. Слепые карманы, образованные не полностью сжатыми зубами-антагонистами, тоннелеобразно соединяют и дренируют. Важным моментом считают одномоментное выполнение первичной пластики местными тканями при истинных дефектах тканей лица с полным восстановлением его структур $[12,13,14]$. Следует проводить иссечение нежизнеспособных тканей, придавая ране геометрически правильную форму (треугольник, ромб или квадрат), что является подготовкой к этапу пластики и облегчает закрытие дефекта местными тканями [7]. Американские исследователи сообщают о положительном опыте восстановления дефекта крыла носа хрящом ушной раковины во время первичной хирургической обработки [15].

Финальным этапом ПХО является наложение швов. Укушенные раны обязательно должны быть дренированы перед ушиванием [7]. Учеными указано, что пренебрежение искусством ушивания ран и формирования швов, стремление к необоснованному упрощению техники и превращению финала операции в незаметную вспомогательную процедуру чреваты развитием осложнений [16,17]. Другие авторы утверждают, что в плане профилактики инфекционных осложнений правильная техника операции часто даже важнее асептики. На линейных участках раны используют внутридермальные швы, в других узловые проленом, отступя 1-1,5 мм от краев раны [18]. Выбор шовного материала для закрытия укушенных ран лица также имеет огромное значение. В эксперименте установлено, что эффективность шва и частота осложнений напрямую зависят от свойств имплантируемого шовного материала (капроаг, викрил, пролен, максон, полисорб), а не от качественного состава микрофлоры раны. Наиболее пригоден для реконструктивных операций полисорб, так как он менее остальных провоцирует местную воспалительную реакцию, не поддерживает воспаление и нагноение, длительно рассасывается. Самой реактогенной нитью исследователи считают капроаг [19]. Полифильные нити, обладающие свойствами фитильности, также поддерживают воспалительный процесс в ране и приводят к образованию лигатурных свищей. От применения кетгута следует отказаться из-за быстрой потери нитью прочности, возможной сенсибилизации [20]. Для обеспечения гладкого течения раневого процесса, приводящего к первичному заживлению раны и образованию тонких, малозаметных рубцов, применяют атравматичные иглы, которые минимально воздействуют на зону вкола, края раны и канал проведения лигатуры [10]. Мы применили на кожу обыкновенный узловатый шов с викрилом №68. Важно избежать избыточного натяжения шовной нити, сближающей ткани. В ином случае лигатура приобретает режущие, пилящие свойства, вокруг нее формируется зона ишемии, некроз, несостоятельность шва или гнойные осложнения [21]. Распределенная и дозированная нагрузка на ткани в зоне пластики имеет первоочередное значение [22,23]. Разработка новых методов хирургического шва и поиск оптимальных способов соединения тканей находятся в поле интересов ведущих хирургических школ[17,24,25]. Важным тактическим моментом является выбор самого шва - узлового или непрерывного, адаптирующего или внутрикожного. Сотни предложенных к настоящему времени швов для целого ряда операций свидетельствуют об отсутствии среди них "идеального" $[17,18]$. Наибольшую физическую герметичность обеспечивает непрерывный шов [25]. Создание оптимальных условий для наложения 
прецизионного шва тонкой нитью позволяет уменьшить травматизацию тканей и сохранить нормальную микроциркуляцию [26]. В литературе нет данных о преимуществах применения того или иного шва при укушенных ранах лица у детей и каких-либо рекомендаций по его применению.

Анализируя причин осложнений лечении укушенных ран лица у детей Паршикова С.А., Косюга С.Ю. (2016) показали, что существующая схема лечения укушенных ран не всегда применима в детской практике, приводит к высокой частоте осложнений и реконструктивных операций. Мы согласны с авторами, что мерами профилактики данных осложнений является, прежде всего, оказанием помощи детям с укушенными ранами лица в специализированном челюстно-лицевом отделении (наш случай 1,2,3). Выполнение ПХО укушенных ран лица у детей в специализированном отделении, в условиях общего обезболивания и с учетом эстетических требований - основные мероприятия по профилактике развития осложнений при лечении укушенных ран лица у детей.

\section{Выводы.}

Лечение укушенных ран лица у детей требует специального комплексного подхода:

1. При ПХО укушенных ран лица требуется тщательная антисептическая обработка, обязательное дренирование, а также ранняя адекватная антибиотикотерапия, так как укушенные раны имеют склонность к нагноению.

2. Ушивание должно быть послойным, с тщательным сопоставлением краев раны и краев естественных отверстий, обязательным ушиванием мимических мышц и пластикой протоков слюнных и слезных желез, что является особенностью

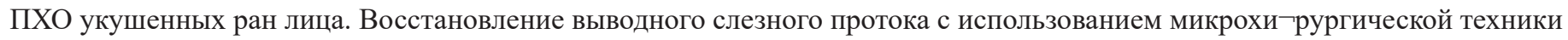
позволяет сохранить функцию органа зрения ребенка и избежать повторных операций.

3. С целью лечения и профилактики образования грубых послеоперационных рубцов после выписки больных из стационара, в амбулаторных условиях обязательно проведение физиотерапевтических мероприятий (курсами) в течение 8-10 месяцев после травмы.

4. Лечение обширных укушенных ран лица у детей в специализированном отделении позволяет достичь лучших эстетических результатов, снизить количество осложнений и потребность в реконструктивных операциях.

5.При оказании помощи вне отделения детской челюстно-лицевой хирургии, во избежание осложнении, следует ограничиться антисептической обработкой раны, гемостазом, наложением повязки, введением цефалоспоринов и направлением в многопрофильный детский стационар.

\section{Литература:}

1. Parshikova S.A., Parshikov V.V. Lechenie ukushennyh ran lica u detej (Treatment of bitten wounds in children) [in Russian]. Pediatrija. 2011; 6(19) : 225-231.

2. Baj A.,Beltramini G. Amputation trauma of the face: surgical techniques and microsurgical replantations. Acta Otorhinolaryngol. Ital.; 2009:29(2):92-96.

3. Chen H. Analysis of pediatric facial dog bites. Craniomaxillofac. Trauma Reconstr. 2013; 6 (4): $225-32$.

4. Petrovich N.I., Mil'gevich T.G., Stajnova O.P. Ukushennye rany lica u detej. Materialy XI ezhegodnogo nauchnogo foruma «Stomatologija 2009». Innovacii i perspektivy v stomatologii i cheljustno-licevoj hirurgii (Bitten face wounds in children. Materials of the XI annual scientific forum "Stomatology 2009". Innovations and perspectives in dentistry and maxillofacial surgery) [in Russian]. M.2009; 294-296.

5. Kljukvin I.Ju., Miguleva I.Ju., Zvezdina M.V., Zimin A.V. Lechenie povrezhdenij ot ukusov sobak i koshek: opyt, vozmozhnosti, problemy (Treatment damage from biting of dogs and cats: experience, opportunities, problems) [in Russian]. Rossijskij medicinskij zhurnal. 2005; 3:52-57.

6. Parshikova S.A., Gljavina I.A., Parshikov V.V., Kosjuga S.Ju., Slesareva O.A. Rol' pervichnoj hirurgicheskoj obrabotki ukushennyh ran lica dlja dostizhenija optimal'nyh jesteticheskih rezul'tatov (The role of primary surgical treatment of the bitten wounds of the face to achieve optimal aesthetic results) [in Russian]. Mezhdunarodnyj nauchno issledovatel'skij zhurnal. 2016; $8(50): 133-135$.

7. Reznikova A.E. Hirurgicheskaja taktika lechenija i reabilitacii detej s ukushennymi ranami lica i shei (Surgical tactics of treatment and rehabilitation of children with bitten by the wounds of the face and neck) [in Russian]. Moskva. 2000;137-142.

8. Urickij A.Ja. CO2 - lazer v kompleksnom lechenii ran posle ukusa zhivotnymi. Annaly plasticheskoj hirurgii (CO2 laser in the complex treatment of wounds after a bite animals. Annals of plastic surgery) [in Russian]. 2005; 2:56-57.

9. Bondarenko, A.L. Analiz jepidemiologicheskoj situacii po beshenstvu v Kirovskoj oblasti (Analysis of the epidemiological situation of rabies in the Kirov region) [in Russian]. Vjatskij medicinskij vestnik. 2010; 5:11.

10. Kosyreva T.M., Sidorova L.N., Buhtarevich S.A. Hirurgicheskaja obrabotka ukushennyh ran lica (Surgical treatment of the bitten wounds of the face) [in Russian]. Sankt-Peterburg. 2003; 461.

11. Izmajlov S.G. Novye tehnologii v hirurgii ran (New technologies in wound surgery) [in Russian]. Nizhnij Novgorod: NizhGMA. 2004;340 p.

12. Popov A.N. Vlijanie vida obezbolivanija na zazhivlenie ran (Influence of the type of anesthesia on the healing of wounds) [in Russian]. Kazan'. 2002;114-115.

13. Wakili N., Gusek-Schneider G.C., Holbach L.M. Eyelid and facial injuries due to dog bites. Klin Monbl Augenheilkd.2001;4:229-31.

14. Schalamon J. Analysis of dog bites in children who are younger than 17 years. Pediatrics. 2006;117:374-9.

15. Kurbanov U.A. Pervichnaja rekonstrukcija ukushennyh defektov mjagkih tkanej nosa i verhnego veka. Annaly plasticheskoj, rekonstruktivnoj i jesteticheskoj hirurgii (Primary reconstruction of bitten soft defects tissues of the nose and upper eyelid. Annals of plastic, reconstructive and aesthetic surgery) [in Russian].2005;3:76-77. 
16. Rapley J.H., Lawrence W.T., Witt P.D. Composite grafting and hyperbaric oxygen therapy in pediatric nasal tip. Ann Plast Surg. 2001;46:434-8.

17. Ovchinnikov V.A., Abelevich A.I. Soedinenie tkanej v hirurgii: Rukovodstvo dlja vrachej (The connection of tissues in surgery: A guide for physicians) [in Russian]. Nizhnij Novgorod: NizhGMA.2005;152.

18. Bodrov A.A. Sovershenstvovanie tehnologii ushivanija posleoperacionnyh ran perednej brjushnoj stenki (Perfection of the technology of suturing the postoperative wounds of the anterior abdominal wall) [in Russian]. Nizhnij Novgorod. 2001.36.

19. Kralja I.V., Nikitina Ju.P. Vybor optimal'nogo shovnogo materiala dlja operacii na trahee (The choice of the optimal suture material for operation on the trachea) [in Russian].Tver'. 2004; 317-319.

20. Adamjan A.A. Dobysh S.V. Biologicheski aktivnye perevjazochnye sredstva $v$ kompleksnom lechenii gnojno-nekroticheskih ran (Biologically active dressings in the complex treatment of purulent-necrotic wounds) [in Russian]. M.: B.i.2000; 39.

21. Izmajlov S.G., Lazarev V.M., Kapustin K.V. Lechenie posleoperacionnyh ventral'nyh gryzh s apparatnym dozirovannym sopostavleniem kraev aponevroticheskogo defekta (reatment of postoperative ventral hernias with a hardware dosage comparison of the edges of the aponeurotic defect.) [in Russian]. Hirurgija.2003; 8: 24-29.

22. Izmajlov S.G. Lechenie posleoperacionnyh ventral'nyh gryzh apparatnym sposobom pod kontrolem vnutribrjushnogo davlenija (reatment of postoperative ventral hernias by a hardware method under the control of intra-abdominal pressure) [in Russian]. Vestnik gerniologii. Moskva.2004;52-59.

23. Lazarev V.M. Lechenie posleoperacionnyh ventral'nyh gryzh s apparatnoj korrekciej aponevroticheskogo defekta (Treatment of postoperative ventral hernias with hardware correction of aponeurotic defect) [in Russian]. N.Novgorod. 2004; $24 \mathrm{~s}$.

24. Muhin A.S., Abramov V.A., Stykut V.Ju., Bashkurov O.E. Opyt primenenija dublikaturnogo shva dlja profilaktiki i lechenija posleoperacionnyh ventral'nyh gryzh(Experience in applying a duplicate seam for the prevention and treatment of postoperative ventral hernias) [in Russian]. Nizh med. zhurnal. 2008; 3:149-150.

25. Vlasov A.P., Kukosh M.V., Saraev V.V., Stepanov Ju.P. Rezekcionnaja hirurgija zheludka. Saransk. 2005; 216:81.McCrary B.F. Hyperbaric oxygen (HBO2) treatment for a failing facial flap. Postgrad Med J. 2007; 83(975):1. 